\title{
PENINGKATAN PRESTASI BELAJAR PAI DENGAN \\ DITERAPKANNYA METODE DEMONSTRASI \\ PADA SISWA KELAS III SD NEGERI 060910 \\ MEDAN DENAI
}

\author{
Nurul Huda Nasution ${ }^{1}$, Arifin Siregar ${ }^{2}$, Irsan Rangkuti ${ }^{3}$ \\ Surel: nurulhudanasution@gmail.com
}

\begin{abstract}
The purpose of this study was to find out the increase in Islamic education learning achievement after the implementation of the demonstration method, and wanted to know the effect of the motivation to learn Islamic education after the demonstration method was applied. This study uses action research as many as three rounds. The target of this study was Class III students of Public Elementary School 060910 Medan Denai. The conclusion of this study is that the contextual teaching model of problem-based teaching model can have a positive effect on the learning achievement and motivation of Class III Elementary School Students 060910 Medan Denai, and this learning model can be used as an alternative learning method for Islamic education.
\end{abstract}

\section{Keywords: Learning Achievement, Demonstration Method}

\begin{abstract}
ABSTRAK
Tujuan dari penelitian ini adalah ingin mengetahui peningkatan prestasi belajar pendidikan Agama Islam setelah diterapkannya metode demonstrasi, dan ingin mengetahui pengaruh motivasi belajar pendidikan Agama Islam setelah diterapkan metode demonstrasi. Penelitian ini menggunakan penelitian tindakan (action research) sebanyak tiga putaran. Sasaran penelitian ini adalah siswa Kelas III SD Negeri 060910 Medan Denai. Simpulan dari penelitian ini adalah metode pengajaran kontekstual model pengajaran berbasis masalah dapat berpengaruh positif terhadap prestasi dan motivasi belajar Siswa Kelas III SD Negeri 060910 Medan Denai, serta model pembelajaran ini dapat digunakan sebagai salah satu alternative pembelajaran pendidikan Agama Islam.
\end{abstract}

Kata Kunci : Prestasi Belajar, Metode Demonstrasi

\section{PENDAHULUAN}

Tujuan dari Pendidikan Agama adalah untuk membimbing anak agar mereka menjadi orang Muslim sejati, beriman teguh, beramal sholeh dan berakhlak mulia serta berguna bagi masyarakat,
Agama dan Negara, (Euharini, dkk. 1977: 25).

Tujuan pendidikan Agama tersebut adalah merupakan tujuan yang hendak dicapai oelh setiap orang yang melaksanakan pendidikan Agama. Karena itu dalam mendidikan agam yang perlu 
ditanamkan terlebih dahuilu adalah keimanan yang teguh, sebab dengan adanya keimanan yang teguh itu maka akan menghasilakan ketaatan menjalankan kewajiban agama.

Titik sentral yang harus dicapai oleh setiap kegiatan belajar mengajar adalah tercapainya tujuan pengajaran. Apa pun yang termasuk perangkat program pengajaran dituntut secara mutlak untuk menunjang tercapainya tujuan. Guru tidak dibenarkan mengajar dengan kemalasan. Anak didik pun diwajibkan mempunyai kreativitas yang tinggi dalam belajar, bukan selalu menanti perintah guru. Kedua unsur manusiawi ini juga beraktivitas tidak lain karena ingin mencapai tujuan secara efektif dan efisien.

\section{METODE PENELITIAN}

Penelitian ini merupakan penelitian tindakan (action research), karena penelitian dilakukan untuk memecahkan masalah pembelajaran di kelas. Penelitian ini juga termasuk penelitian deskriptif, sebab menggambarkan bagaimana suatu teknik pembelajaran diterapkan dan bagaimana hasil yang diinginkan dapat dicapai. .

Subyek penelitian adalah siswa-siswi Kelas III SD Negeri 060910 Medan Denai Pelajaran 2017/2018 pada pokok bahasan sholat.

Penelitian ini dilakukan melalui tiga tahap, yaitu: (1) tahap persiapan, (2) tahap pelaksanaan, dan (3) tahap penyelesaian.
1. TahapPersiapan

Kegiatan yang dilakukan dalam tahap persiapan ini adalah mempersiapkan segala sesuatu yang berhubungan dengan pelaksanaan penelitian. Dalam kegiatan ini diharapkan pelaksanaan penelitian akan berjalan lancer dan mencapai tujuan yang diinginkan. Kegiatan persiapan ini meliputi: (1) kajian pustaka, (2) penyusunan rancangan penelitian, (3) orientasi lapangan, dan (4) penyusunan instrumen penelitian.

Dalam rangka menyusun dan mengolah data yang terkumpul sehingga dapat mengahsilkan suatu kesimpulan yang dapat dipertanggungjawabkan, maka digunakan analisis data kuantitatif dan pada metode observasi digunakan data kualitatif. Cara perhitungan untuk mengetahui ketuntasan belajar siswa dalam proses belajar mengajar sebagai berikut:

1. Merekapitulasi hasil tes.

2. Menghitung jumlah skor yang tercapai dan prosentasenya untuk masingmasing siswa dengan menggunakan rumus ketuntasan belajar seperti yang terdapat dalam buku petunjuk teknis penilaian yaitu siswa dikatakan tuntas secara individual jika mendapatkan nilai minimal 65, sedangkan secara klasikal dikatakan tuntas belajar jika jumlah siswa yang tuntas 
secara individu mencapai $85 \%$ yang telah mencapai daya serap lebih dari sama dengan $65 \%$.

3. Menganalisis hasil observasi yang dilakukan oleh teman sejawat pada aktivitas guru dan siswa selama kegiatan belajar mengajar berlangsung.

\section{HASIL DAN PEMBAHASAN}

1. Siklus I

a. Tahap Perencanaan

Pada tahap ini peneliti mempersiapkan perangkat pembelajaran yang terdiri dari rencana pelajaran 1 , soal tes formatif 1 dan alat-alat pengajaran yang mendukung. Selain itu juga dipersiapkan lembar observasi pengelolaan metode demonstrasi, dan lembar observasi aktivitas guru dan siswa.

\section{b. Tahap Kegiatan dan Pelaksanaan \\ Pelaksanaan kegiatan belajar} mengajar untuk siklus I dilaksanakan pada tanggal 13 September 2018 di Kelas III dengan jumlah siswa 27 siswa. Dalam hal ini peneliti bertindak sebagai pengajar, sedangkan yang bertindak sebagai pengamat adalah Kepala Sekolah SD Negeri 060910 Kec Medan Denai Pelajaran 2017/2018. Adapun proses belajar mengajar mengacu pada rencana pelajaran yang telah dipersiapkan. Pengamatan (observasi) dilaksanakan bersamaan dengan pelaksaaan belajar mengajar.
Pada akhir proses belajar mengajar siswa diberi tes formatif I dengan tujuan untuk mengetahui tingkat keberhasilan siswa dalam proses belajar mengajar yang telah dilakukan.

Tabel 4.4. Rekapitulasi Hasil

Tes Formatif Siswa Pada Siklus I

\begin{tabular}{c|l|c}
\hline No & \multicolumn{1}{|c|}{ Uraian } & $\begin{array}{c}\text { Hasil } \\
\text { Siklus I }\end{array}$ \\
\hline 1 & Nilai rata-rata tes & $\mathbf{7 0 , 4 9}$ \\
2 & formatif & 27 \\
3 & Jumlah siswa yang & $\mathbf{6 5 , 8 5}$ \\
& tuntas belajar & \\
& Persentase & \\
& ketuntasan belajar & \\
\hline
\end{tabular}

$\begin{array}{rrr}\text { Dari tabel di atas dapat } \\ \text { dijelaskan } & \text { bahwa } & \text { dengan }\end{array}$
menerapkan metode demonstrasi diperoleh nilai rata-rata prestasi belajar siswa adalah 70,49 dan ketuntasan belajar mencapai $65,85 \%$ atau ada 27 siswa dari 41 siswa sudah tuntas belajar. Hasil tersebut menunjukkan bahwa pada siklus pertama secara klasikal siswa belum tuntas belajar, karena siswa yang memperoleh nilai $\geq 65$ hanya sebesar $65,85 \%$ lebih kecil dari persentase ketuntasan yang dikehendaki yaitu sebesar 85\%. Hal ini disebabkan karena siswa masih merasa baru dan belum mengerti apa yang dimaksudkan dan digunakan guru dengan menerapkan metode demonstrasi.

c. Refleksi

Dalam pelaksanaan kegiatan belajar mengajar diperoleh informasi dari hasil pengamatan sebagai berikut: 
1) Guru kurang maksimal dalam memotivasi siswa dan dalam menyampaikan tujuan pembelajaran

2) Guru kurang maksimal dalam pengelolaan waktu

3) Siswa kurang aktif selama pembelajaran berlangsung

d. Refisi

Pelaksanaan kegiatan belajar mengajar pada siklus I ini masih terdapat kekurangan, sehingga perlu adanya revisi untuk dilakukan pada siklus berikutnya.

1) Guru perlu lebih terampil dalam memotivasi siswa dan lebih jelas dalam menyampaikan tujuan pembelajaran. Dimana siswa diajak untuk terlibat langsung dalam setiap kegiatan yang akan dilakukan.

2) Guru perlu mendistribusikan waktu secara baik dengan menambahkan informasiinformasi yang dirasa perlu dan

2. Siklus II

a. Tahap perencanaan

Pada tahap ini peneliti mempersiapkan perangkat pembelajaran yang terdiri dari rencana pelajaran 2 , soal tes formatif 2 dan alat-alat pengajaran yang mendukung. Selain itu juga dipersiapkan lembar observasi pengelolaan metode demonstrasi dan lembar observasi guru dan siswa.

b. Tahap kegiatan dan pelaksanaan

Pelaksanaan kegiatan belajar mengajar untuk siklus II dilaksanakan pada tanggal 13
September 2018 di Kelas III dengan jumlah siswa 20 siswa. Dalam hal ini peneliti bertindak sebagai pengajar, sedangkan yang bertindak sebagai pengamat adalah Kepala Sekolah SD Negeri 060910 Medan Denai. Adapun proses belajar mengajar mengacu pada rencana pelajaran dengan memperhatikan revisi pada siklus I, sehingga kesalahan atau kekurangan pada siklus I tidak terulang lagi pada siklus II. Pengamatan (observasi) dilaksanakan bersamaan dengan pelaksanaan belajar mengajar.

Dengan penyempurnaan aspek-aspek di atas dalam penerapan metode demonstrasi diharapkan siswa dapat menyimpulkan apa yang telah mereka pelajari dan mengemukakan pendapatnya sehingga mereka akan lebih memahami tentang apa yang telah mereka lakukan.

Aktivitas guru yang paling dominan pada siklus II adalah membimbing dan mengamati siswa dalam menemukan konsep yaitu $25 \%$. Jika dibandingkan dengan siklus I, aktivitas ini mengalami peningkatan. Aktivitas guru yang mengalami penurunan adalah memberi umpan balik/evaluasi/tanya jawab (16,6\%), menjelaskan materi yang sulit $(11,7)$. Meminta siwa mendiskusikan dan menyajikan hasil kegiatan $(8,2 \%)$, dan membimbing siswa merangkum pelajaran $(6,7 \%)$.

Sedangkan untuk aktivitas siswa yang paling dominan pada siklus II adalah Bekerja dengan 
sesama teman sebangku yaitu (21\%). Jika dibandingkan dengan siklus I, aktivitas ini mengalami peningkatan. Aktivitas siswa yang mengalami penurunan adalah mendengarkan atau memperhatikan penjelasan guru (17,9\%). Diskusi antar siswa atau antara siswa dengan guru $(13,8 \%)$, menulis yang relevan dengan $\mathrm{KBM}$ $(7,7 \%)$ dan merangkum pembelajaran $(6,7 \%)$. Adapun aktivitas siswa yang mengalami peningkatan adalah membaca buku $(12,1 \%)$, menyajikan hasil pembelajaran $\quad(4,6 \%)$, menanggapi/mengajukan

pertanyaan/ide $\quad(5,4 \%), \quad$ dan mengerjakan tes evaluasi $(10,8 \%)$.

Berikutnya adalah rekapitulasi hasil tes formatif siswa terlihat pada tabel berikut.

Tabel 4.7. Rekapitulasi Hasil Tes Formatif Siswa Pada Siklus II

\begin{tabular}{c|l|c}
\hline No & \multicolumn{1}{|c|}{ Uraian } & $\begin{array}{c}\text { Hasil } \\
\text { Siklus II }\end{array}$ \\
\hline 1 & Nilai rata-rata tes & $\mathbf{7 3 , 9 0}$ \\
2 & formatif & $\mathbf{3 2}$ \\
3 & Jumlah siswa yang & $\mathbf{7 8 , 0 0}$ \\
& tuntas belajar & \\
& Persentase & \\
& ketuntasan belajar & \\
\hline
\end{tabular}

Dari tabel di atas diperoleh nilai rata-rata prestasi belajar siswa adalah 73,90 dan ketuntasan belajar mencapai $78,00 \%$ atau ada 16 siswa dari 27 siswa sudah tuntas belajar. Hasil ini menunjukkan bahwa pada siklus II ini ketuntasan belajar secara klasikal telah mengalami peningkatan sedikit lebih baik dari siklus I. Adanya peningkatan hasil belajar siswa ini karena setelah guru menginformasikan bahwa setiap akhir pelajaran akan selalu diadakan tes sehingga pada pertemuan berikutnya siswa lebih termotivasi untuk belajar. Selain itu siswa juga sudah mulai mengerti apa yang dimaksudkan dan dinginkan guru dengan menerapkan metode demonstrasi.

c. Refleksi

Dalam pelaksanaan kegiatan belajar diperoleh informasi dari hasil pengamatan sebagai berikut:

1) Memotivasi siswa

2) Membimbing siswa merumuskan kesimpulan/menemukan konsep

3) Pengelolaan waktu

d. Refisi Rancangan

Pelaksanaan kegiatan belajar pada siklus II ini masih terdapat kekurangan-kekurangan. Maka perlu adanya revisi untuk dilaksanakan pada siklus II antara lain:

1) Guru dalam memotivasi siswa hendaknya dapat membuat siswa lebih termotivasi selama proses belajar mengajar berlangsung.

2) Guru harus lebih dekat dengan siswa sehingga tidak ada perasaan takut dalam diri siswa baik untuk mengemukakan pendapat atau bertanya.

3. Siklus III

a. Tahap Perencanaan

Pada tahap ini peneliti mempersiapkan perangkat pembelajaran yang terdiri dari rencana pelajaran 3 , soal tes formatif 3 dan alat-alat pengajaran yang mendukung. Selain itu juga dipersiapkan lembar observasi 
pengelolaan metode demonstrasi dan lembar observasi aktivitas guru dan siswa.

b. Tahap kegiatan dan pengamatan

Pelaksanaan kegiatan belajar mengajar untuk siklus III dilaksanakan pada tanggal 20 November 2018 di Kelas III dengan jumlah siswa 20 siswa. Dalam hal ini peneliti bertindak sebagai pengajar, sedangkan yang bertindak sebagai pengamat adalah Kepala Sekolah SD Negeri 060910 Medan Denai. Adapun proses belajar mengajar mengacu pada rencana pelajaran dengan memperhatikan revisi pada siklus II, sehingga kesalahan atau kekurangan pada siklus II tidak terulang lagi pada siklus III. Pengamatan (observasi) dilaksanakan bersamaan dengan pelaksanaan belajar mengajar.

Aktivitas guru yang paling dominan pada siklus III adalah membimbing dan mengamati siswa dalam menemukan konsep yaitu 22,6\%, sedangkan aktivitas menjelaskan materi yang sulit dan memberi umpan balik/evaluasi/tanya jawab menurun masing-masing sebesar (10\%) dan (11,7\%). Aktivitas lain yang mengalami peningkatan adalah mengaitkan dengan pelajaran sebelumnya (10\%), menyampaikan materi/strategi /langkah-langkah $(13,3 \%)$, meminta siswa memikirkan untuk lebih memahami materi pelajaran (10\%), dan membimbing siswa merangkum pelajaran (10\%). Adapun aktivitas yang tidak mengalami perubaan adalah menyampaikan tujuan $(6,7 \%)$ dan memotivasi siswa $(6,7 \%)$.

Sedangkan untuk aktivitas siswa yang paling dominan pada siklus III adalah Bekerja dengan sesama teman sebangku yaitu $(22,1 \%)$ dan mendengarkan/memperhatikan penjelasan guru (20,8\%), aktivitas yang mengalami peningkatan adalah membaca buku siswa $(13,1 \%)$ dan diskusi antar siswa/antara siswa dengan guru (15,0\%). Sedangkah aktivitas yang lainnya mengalami penurunan.

Berikutnya adalah rekapitulasai hasil tes formatif siswa seperti terlihat pada tabel berikut.

Tabel 4.10. Hasil Tes Formatif Siswa pada Siklus III

\begin{tabular}{c|l|c}
\hline No & \multicolumn{1}{|c|}{ Uraian } & $\begin{array}{c}\text { Hasil } \\
\text { Siklus III }\end{array}$ \\
\hline 1 & Nilai rata-rata tes & $\mathbf{7 7 , 8 0}$ \\
2 & formatif & $\mathbf{3 6}$ \\
3 & Jumlah siswa yang & $\mathbf{8 7 , 8 0}$ \\
& tuntas belajar & \\
& Persentase & \\
& ketuntasan belajar & \\
\hline
\end{tabular}

Berdasarkan tabel diatas diperoleh nilai rata-rata tes formatif sebesar 77,80 dan dari 41 siswa yang telah tuntas sebanyak 35 siswa dan 5 siswa belum mencapai ketuntasan belajar. Maka secara klasikal ketuntasan belajar yang telah tercapai sebesar 87,80\% (termasuk kategori tuntas). Hasil pada siklus III ini mengalami peningkatan lebih baik dari siklus II. Adanya peningkatan 
hasil belajar pada siklus III ini dipengaruhi oleh adanya peningkatan kemampuan guru dalam menerapkan metode demonstrasi sehingga siswa menjadi lebih terbiasa dengan pembelajaran seperti ini sehingga siswa lebih mudah dalam memahami materi yang telah diberikan.

c. Refleksi

Pada tahap ini akah dikaji apa yang telah terlaksana dengan baik maupun yang masih kurang baik dalam proses belajar mengajar dengan penerapan metode demonstrasi. Dari data-data yang telah diperoleh dapat duraikan sebagai berikut:

1) Selama proses belajar mengajar guru telah melaksanakan semua pembelajaran dengan baik. Meskipun ada beberapa aspek yang belum sempurna, tetapi persentase pelaksanaannya untuk masing-masing aspek cukup besar.

2) Berdasarkan data hasil pengamatan diketahui bahwa siswa aktif selama proses belajar berlangsung.

3) Kekurangan pada siklus-siklus sebelumnya sudah mengalami perbaikan dan peningkatan sehingga menjadi lebih baik.

4) Hasil belajar siswsa pada siklus III mencapai ketuntasan.

d. Revisi Pelaksanaan

Pada siklus III guru telah menerapkan metode demonstrasi dengan baik dan dilihat dari aktivitas siswa serta hasil belajar siswa pelaksanaan proses belajar mengajar sudah berjalan dengan baik. Maka tidak diperlukan revisi terlalu banyak, tetapi yang perlu diperhatikan untuk tindakan selanjutnya adalah memaksimalkan dan mempertahankan apa yang telah ada dengan tujuan agar pada pelaksanaan proses belajar mengajar selanjutnya penerapan metode demonstrasi dapat meningkatkan prosesbelajar mengajar sehingga tujuan pembelajaran dapat tercapai

\section{Pembahasan}

1. Ketuntasan Hasil belajar Siswa

Melalui hasil penelitian ini menunjukkan bahwa metode demonstrasi memiliki dampak positif dalam meningkatkan prestasi belajar siswa. Hal ini dapat dilihat dari semakin mantapnya pemahaman siswa terhadap materi yang disampaikan guru (ketuntasan belajar meningkat dari siklus I, II, dan III) yaitu masing-masing $65,85 \%$, $78,00 \%$, dan $87,80 \%$. Pada siklus III ketuntasan belajar siswa secara klasikal telah tercapai.

2. Kemampuan Guru dalam Mengelola Pembelajaran

Berdasarkan analisis data, diperoleh aktivitas siswa dalam proses belajar mengajar dengan menerapkan metode demonstrasi dalam setiap siklus mengalami peningkatan. Hal ini berdampak positif terhadap prestasi belajar siswa yaitu dapat ditunjukkan dengan meningkatnya nilai rata-rata siswa pada setiap siklus yang terus mengalami peningkatan.

3. Aktivitas Guru dan Siswa Dalam Pembelajaran 
Berdasarkan analisis data, diperoleh aktivitas siswa dalam proses pembelajaran Pendidikan Agama Islam pada pada pokok bahasan sholat dengan metode demonstrasi yang paling dominan adalah Bekerja dengan sesama teman sebangku,

mendengarkan/memperhatikan penjelasan guru, dan diskusi antar siswa/antara siswa dengan guru. Jadi dapat dikatakan bahwa aktivitas siswa dapat dikategorikan aktif.

Sedangkan untuk aktivitas guru selama pembelajaran telah melaksanakan langkah-langkah kegiatan belajar mengajar dengan menerapkan metode demonstrasi dengan baik. Hal ini terlihat dari aktivitas guru yang muncul di antaranya aktivitas membimbing dan mengamati siswa dalam menemukan konsep, menjelaskan materi yang sulit, memberi umpan balik/evaluasi/tanya jawab dimana prosentase untuk aktivitas di atas cukup besar.

\section{SIMPULAN}

Berdasarkan hasil penelitian yang telah dipaparkan selama tiga siklus, hasil seluruh pembahasan serta analisis yang telah dilakukan dapat disimpulkan sebagai berikut:

1. Metode demonstrasi memiliki dampak positif dalam meningkatkan prestasi belajar siswa yang ditandai dengan peningkatan ketuntasan belajar siswa dalam setiap siklus, yaitu siklus I $(65,85 \%)$, siklus II $(78,00 \%)$, siklus III $(87,80 \%)$.

2. Metode demonstrasi dapat menjadikan siswa merasa dirinya mendapat perhatian dan kesempatan untuk menyampaikan pendapat, gagasan, ide dan pertanyaan.

3. Penerapan metode demonstrasi mempunyai pengaruh positif, yaitu dapat meningkatkan motivasi belajar siswa.

Dari hasil penelitian yang diperoleh dari uraian sebelumnya agar proses belajar mengajar Pendidikan Agama Islam lebih efektif dan lebih memberikan hasil yang optimal bagi siswa, maka disampaikan saran sebagai berikut:

1. Untuk melaksanakan metode demonstrasi memerlukan persiapan yang cukup matang, sehingga guru harus mampu menentukan atau memilih topik yang benar-benar bisa diterapkan dengan metode demonstrasi dalam proses belajar mengajar sehingga diperoleh hasil yang optimal.

2. Dalam rangka meningkatkan prestasi belajar siswa, guru hendaknya lebih sering melatih siswa dengan berbagai metode pengajaran, walau dalam taraf yang sederhana, dimana siswa nantinya dapat menemukan pengetahuan baru, memperoleh konsep dan keterampilan, sehingga siswa berhasil atau mampu memecahkan masalahmasalah yang dihadapinya. 
3. Perlu adanya penelitian yang lebih lanjut, karena hasil penelitian ini hanya dilakukan di SD Negeri 060910 Medan Denai Pelajaran 2017/2018.

4. Untuk penelitian yang serupa hendaknya dilakukan perbaikanperbaikan agar diperoleh hasil yang lebih baik.

\section{DAFTAR RUJUKAN}

Ali, Muhammad. 1996. Guru Dalam

Proses Belajar Mengajar. Bandung: Sinar Baru Algesindon.

Arikunto. 1993. Manajemen Mengajar Secara Manusiawi. Jakarta: Rineksa Cipta.

Arikunto, Suharsimi. 2001. Dasardasar Evaluasi Pendidikan. Jakarta: Bumi Aksara.

Arikunto, Suharsimi. 2002. Prosedur Penelitian Suatu Pendekatan Praktek. Jakarta: Rineksa Cipta.

Azhar, Lalu Muhammad. 1993. Proses Belajar Mengajar Pendidikan. Jakarta: Usaha Nasional

Daroeso, Bambang. 1989. Dasar dan Konsep Pendidikan Moral Pancasila. Semarang: Aneka Ilmu.
Djamarah, Syaiful Bahri. 2002. Strategi Belajar Mengajar. Jakarta: Rineksa Cipta.

Djamarah. Syaiful Bahri. 2002. Psikologi Belajar. Jakarta: Rineka Cipta.

Hadi, Sutrisno. 1982. Metodologi Research, Jilid 1. Yogyakarta: YP. Fak. Psikologi UGM.

Hamalik, Oemar. 2002. Psikologi Belajar dan Mengajar. Bandung: Sinar Baru Algesindo.

Hasibuan. J.J. dan Moerdjiono. 1998. Proses Belajar Mengajar. Bandung: Remaja Rosdakarya.

Margono. 1997. Metodologi Penelitian Pendidikan. Jakarta. Rineksa Cipta.

Masriyah. 1999. Analisis Butir Tes. Surabaya: Universitas Press.

Ngalim, Purwanto M. 1990. Psikologi Pendidikan. Bandung: PT. Remaja Rosdakarya.

Nur, Moh. 2001. Pemotivasian Siswa untuk Belajar. Surabaya. University Press. Universitas Negeri Surabaya. 
Ramayulis, 2004. Metodologi Pendidikan Agama Islam. Jakarta: Kalam Mulia.

Rustiyah, N.K. 1991. Strategi Belajar Mengajar. Jakarta: Bina Aksara.

Sardiman, A.M. 1996. Interaksi dan Motivasi Belajar Mengajar. Jakarta: Bina Aksara.

Soekamto, Toeti. 1997. Teori Belajar dan Model Pembelajaran. Jakarta: PAU-PPAI, Universitas Terbuka.

Sukidin, dkk. 2002. Manajemen Penelitian Tindakan Kelas. Surabaya: Insan Cendekia.

Surakhmad, Winarno. 1990. Metode Pengajaran Nasional. Bandung: Jemmars.

Suryosubroto, B. 1997. Proses Belajar Mengajar di Sekolah. Jakarta: PT. Rineksa Cipta.

Syah, Muhibbin. 1995. Psikologi Pendidikan, Suatu Pendekatan Baru. Bandung: Remaja Rosdakarya. 